DOI 10.37882/2500-3682.2021.05.02

\title{
ПСИХОЛОГИЧЕСКАЯ МОДЕЛЬ РАЗВИТИЯ НРАВСТВЕННОГО СОЗНАНИЯ ОБУЧАЮЩИХСЯ В ПРОЦЕССЕ ИЗУЧЕНИЯ ИНОСТРАННЫХ ЯЗЫКОВ
}

\section{A PSYCHOLOGICAL MODEL OF THE DEVELOPMENT OF STUDENTS'MORAL CONSCIOUSNESS IN THE PROCESS OF LEARNING FOREIGN LANGUAGES}

M. Aipova

I. Ganischina

Summary: The article presents a psychological model of the development of the moral consciousness of students in the process of learning foreign languages, which includes a social order, the concept of moral consciousness, its structure, psychological conditions for development, a complex of psychodiagnostic methods, the author's psychological program and the result. The purpose of its creation is to develop a psychological model for the development of the moral consciousness of students in the process of learning foreign languages. The structure of students' moral consciousness includes cognitive, motivational-needbased, spiritual-moral, communicative-reflexive, emotional-volitional components. The result of using the psychological model is the training of highly qualified personnel with a high level of moral consciousness.

Keywords: moral consciousness, structure of moral consciousness, components of moral consciousness, students, development, foreign language.
Аипова Марина Маратовна

старший преподаватель, Рязанский государственный университет им. С.А. Есенина

enigmarina_1@hotmail.com

Ганишина Ирина Сергеевна

Д.псх.н., доцент, Академия права и управления

Федеральной службы исполнения наказаний, г. Рязань irinaganishina@yandex.ru

Аннотация: B статье представлена психологическая модель развития нравственного сознания обучающихся в процессе изучения иностранных языков, включающая в себя социальный заказ, понятие нравственного сознания, его структуру, психологические условия развития, комплекс психодиагностических методов, авторскую психологическую программу и результат. Целью ее создания - разработка психологической модели развития нравственного сознания обучающихся в процессе изучения иностранных языков. В структуру нравственного сознания обучающихся входят когнитивный, мотивационнопотребностный, духовно-нравственный, коммуникативно-рефлексивный, эмоционально-волевой компоненты. Результатом использования психологической модели является подготовка высококвалифицированных кадров с высоким уровнем нравственного сознания.

Ключевые слова: нравственное сознание, структура нравственного сознания, компоненты нравственного сознания, обучающиеся, развитие, иностранный язык.
$\mathrm{B}$ последние годы в системе высшего образования Российской Федерации высокую актуальность приобретает профессиональная подготовка будущих специалистов, владеющих знаниями, умениями, навыками, профессиональными компетенциями и обладающих высоким уровнем профессионально-значимых качеств.

Проведенный нами теоретико-методологический анализ исследуемой проблемы показал, что при изучении иностранного языка важнейшую роль имеет развитие нравственного сознания обучающихся, так как знакомство с культурой, искусством, художественной литературой другой страны, государственным устройством, социокультурными особенностями ее жителей имеет огромный ресурс для развития нравственного сознания.

В контексте исследуемой проблемы важно отметить, что проблема разработки модели развития нравственного сознания обучающихся в процессе изучения иностранных языков имеет особую актуальность для выс- ших учебных заведений России. Это обусловлено тем, что обучение в вузе имеет не только образовательные и развивающие, но и воспитательные задачи. Поэтому развитие нравственного сознания обучающихся в рамках подготовки высококвалифицированных кадров имеет сегодня первостепенное значение.

В психологии исследованием нравственного сознания обучающихся занимались Л.Н. Антилогова [2], В.В. Рыжов [4], М.А. Фабулова[5] и другие ученые. Авторы доказали возможность развития нравственного сознания в процессе получения высшего образования.

По данным Г.И. Аксеновой [1], процесс обучения в вузе предполагает, что личностная активность студентов проявляется в становлении обучающихся как субъекта деятельности, так как у них возникает особое отношение к ней. Поэтому необходима деятельностная система организации профессионального обучения, что обеспечивает эффективное развитие у обучающихся нравственного сознания. 
Теоретическая модель развития нравственного сознания обучающихся в процессе изучения иностранных языков включает в себя социальный заказ, понятие и структуру нравственного сознания, психологические условия, комплекс психодиагностических методов, авторскую психологическую программу, результат. Целью ее создания - разработка психологической модели развития нравственного сознания обучающихся в процессе изучения иностранных языков.

Социальный заказ государства включает в себя подготовку высококвалифицированных специалистов с высоким уровнем развития нравственного сознания.

Центральным элементом модели является понятие «нравственное сознание». Нравственное сознание - это интегративное личностное образование, включающее в себя мотивы, ценности, знания, нравственные качества, обладающее свойствами целеполагания, направленности, рефлексивности и формирующееся под влиянием внешних (социокультурных) и внутренних (психологических) факторов.

Структура нравственного сознания обучающихся включает в себя когнитивный, мотивационно-потребностный, духовно-нравственный, коммуникативнорефлексивный, эмоционально-волевой компоненты. Когнитивный компонент содержит убеждения, знания, профессиональные компетенции, ориентированные на развитие нравственного сознания обучающихся. Мотивационно-потребностный компонент включает в себя целенаправленную деятельность, движимую личностными потребностями, мотивами, интересами обучающихся. Духовно-нравственный компонент- это мировоззрение, морально-нравственные установки личности обучающихся. Коммуникативно-рефлексивный компонент подразумевает нравственную направленность личности в процессе общения с окружающими, осознание своих поступков. Эмоционально-волевой компонент представляет собой субъективные отношения обучающихся к различным сторонам действительности (эмоциональная устойчивость и самоконтроль).

Комплекс психодиагностических методов, направленных на изучение уровня развития нравственного сознания обучающихся, включает в себя использование наблюдения, опроса, тестирования, методов математической статистики (корреляционный анализ, U-критерий Манна-Уитни, Т-критерий Вилкоксона, коэффициент ранговой корреляции Спирмена). С целью выявления уровня развития нравственного сознания используются следующие психодиагностические методики: «Ценностные ориентации» (М. Рокича), 16 - PF (формы А) (Р.Б. Кеттелла), Краткий ориентировочный тест (В.Н. Бузин, Э.Ф. Вандерлик), комплексная методика диагностики мотивов владения и использования иностранного язы- ка (Н.А. Емельянова, В.В. Рыжов, М.П. Гришаев), уровень нравственных качеств - опросник (Г. Гибш, М. Форверг), методика «Уровень развития нравственных качеств личности» (И.И. Купцов, Т.В. Пивоварова), Методика «Ваша коммуникативная установка» (В.В. Бойко), шкалы теста оптимальности самооценки (Н.М. Пейсахов), опросник субъективной локализации контроля (СЛК) (С.Р. Пантилеев, В.В. Столин), шкала личностных стратегий преодоления жизненных трудностей (С. Хобфолл), авторский опросник по изучению нравственного сознания обучающихся.

В процессе реализации психологической модели следует выделить следующие психологические условия, влияющие на развитие нравственного сознания обучающихся в процессе изучения иностранных языков: 1) психологическое воздействие среды высшего учебного заведения; 2) ценностно-нравственное содержание занятий с диалогической направленностью иноязычного общения; 3) воздействие культурной среды иноязычного общения в учебно-речевой деятельности. Рассмотрим их более подробно.

Психологическое воздействие среды высшего учебного заведения изучено Сундуковой В.В., Ганишиной И.С. [3]. Оно означает преднамеренное влияние образовательной среды на психические состояния, мысли и поступки обучающихся. Реализация психологического воздействия преподавателей на процесс развития нравственного сознания обучающихся заключается в создании целенаправленной нравственно-ориентированной воспитательной среды, оказывающей влияние на развитие нравственного сознания обучающихся.

Ценностно-нравственное содержание занятий с диалогической направленностью иноязычного общения состоит в том, что обучающийся в процессе образовательной деятельности принимает общечеловеческие правила и нормы в качестве принципов своего поведения, реализации их во внутренней потребности. Преобразовываясь в личностном плане, внешние требования превращаются во внутренние.

Важно отметить, что для будущих педагогов, переводчиков характерно постоянное расширение мировоззрения, толерантности, детерминированных воспитательной и учебной работой. Внедрение в учебный процесс занятий с диалогической направленностью, ориентированных на воспитание студентов на основе нравственных ценностей, - важное условие развития нравственного сознания обучающихся, являющихся залогом готовности к принятию самостоятельных решений в ситуациях нравственного выбора.

Воздействие культурной среды иноязычного общения в учебно-речевой деятельности. Культурная среда, 
способствующая развитию нравственного сознания, обусловливает последовательность изучения материала, развитие культурного и страноведческого аспектов, сформированность у студентов знаний о профессионально ценных нравственных качествах. Задача преподавателя заключается в привлечении обучающихся К изучению источников, связанных с проблемой нравственного выбора личности. В рамках данного направления необходима планомерная работа с обучающимися по реализации различных форм развития нравственных ценностей, которые осуществляются посредством организации культурных мероприятий и праздников, встреч с носителями иностранного языка, воспитательных бесед.

Развитие нравственного сознания обучающихся в процессе изучения иностранных языков включает в себя реализацию авторской психологической программы, состоящей из двух блоков: психологического и психолингвистического. Психологический блок предполагает чтение обучающимся лекций по развитию нравственного сознания, проведение групповых психологических мероприятий, направленных на развитие нравственного сознания, участие в социально-психологических тренингах по вопросам развития нравственных качеств. Психолингвистический блок подразумевает изучения художественных произведений нравственного содержания на иностранном языке, проведение дискуссий и конкурсов переводов, организацию встреч с носителями языка, знакомство с культурой другой страны и др.

Результатом использования психологической модели развития нравственного сознания обучающихся в процессе изучения иностранных языков является подготовка высококвалифицированных кадров с высоким уровнем нравственного сознания.

\section{ЛИТЕРАТУРА}

1. Аксенова, Г.И. Психология и педагогика становления субъекта / Г.И. Аксенова. - М.; Рязань: РИНФ0, 1999. - 210 с.

2. Антилогова, Л.Н. Психологические механизмы развития нравственного сознания личности: дис. ... д-ра психол. наук : 19.00 .01 / Л. Н. Антилогова. Новосибирск, 1999. - 434 с.

3. Ганишина, И.С., Сундукова В.В. О концептуальной модели антикоррупционной направленности курсантов образовательных организаций Федеральной службы исполнения наказаний России. И.С. Ганишина, В.В. Сундукова // Ученые записки университета им. П.Ф. Лесгафта. - 2020. - № 6 (184). C. 433-436.

4. Рыжов, В.В. Личность: творчество и духовность / В.В. Рыжов.- СПб.: Изд-во Санкт-Петербургского христианского ун-та, 2012.- 489 с.

5. Фабулова, М.А. Психологические условия формирования нравственного сознания студентов-медиков средствами иностранного языка : дис. ... канд. психолог. наук : 19.00.07 / Фабулова Марина Александровна. Нижний Новгород, 2013. - 193 с. 